\title{
Properties of materials for advanced technology of joint utilization of man-made waste
}

\author{
Igor N. Tanutrov, ${ }^{*}$ Marina N. Sviridova, ${ }^{+}$Sergey A. Lyamkin, Yury A. Chesnokov, \\ Lyubov A. Ovchinnikova, and Larisa A. Marshuk \\ Institute of Metallurgy of Ural Branch of Russian Academy of Sciences. Amundsen St., 101. Ekaterinburg, \\ 620016. Sverdlovsk Region. Russia.Phone:+7 (904)380-56-57.E-mail: intan38@live.ru
}

*Supervising author; ${ }^{+}$Corresponding author

Keywords: red mud, oiled mill scale, chemical, phase, granulometric, composition, specific surface.

Abstract
With the aim of improving the technology of co-processing of red mud (RM) and oily mill scale free (OMS) using co-temporal methods and apparatus, including using equipment of the center «Ural-M», studied the physico-chemical properties of industrial wastes.

The main components of RM are: $\mathrm{Fe}(35.7 \%)$ in the form of hematite and complex hydroalumination, $\mathrm{Ca}(11.0 \%)$ in the form of calcite and hydro-aluminosilicates, $\mathrm{Al}(6.8 \%)$ and $\mathrm{Si}(4.7 \%)$ in the composition of hydroalumination, $\mathrm{Na}(2.8 \%)$ in the form of hydroalumination, carbonate and hydroxide, $\mathrm{Ti}(2.5 \%)$ in the form of rutile. The sludge moisture content was $11.9 \%$. The main components of the OMS are: Fe (71\%) in the form of magnetite, wustite and hematite with a very small amount of fayalite. The contents of Si (in the form of quartz), $\mathrm{Al}$ and $\mathrm{P}$ (non-forming phases) are within 1-3\%. Humidity OMS $-16.3 \%$, the content of indelible organic matter $-4.0 \%$.

Granulometric composition of RM is characterized by high dispersion. With an average diameter of 1.6 $\mu \mathrm{m}$, all particle sizes are in the range of 0.5-12 $\mu \mathrm{m}$. Granulometric composition of OMS is characterized by complexity. With an average diameter of $8.6 \mu \mathrm{m}$, maxima of $0.9 \mu \mathrm{m}$ and $15 \mu \mathrm{m}$ and a minimum of about 1.2 $\mu \mathrm{m}$ are observed in the particle size distribution. The specific surface area of the materials is equal to RM 23.7 $\mathrm{m}^{2} / \mathrm{g}$, and $\mathrm{OMS}-1.9 \mathrm{~m}^{2} / \mathrm{g}$.

The change of waste properties after exposure to aqueous solutions of alkalis and acids neutralizing the effect of organic (OMS) and alkaline (RM) surface compounds was studied. Neutralization of aqueous suspension with $\mathrm{HCl}$ solution leads to removal of alkaline film from the surface. As a result of the impact of reagents, there is a decrease in the content of water-soluble components in the processing products. At the same time, the average particle sizes of RM and OMS increase to 2 and $14 \mu \mathrm{m}$, respectively, and the specific surface area to 25.7 and $2.3 \mathrm{~m}^{2} / \mathrm{g}$. The distribution of particle size of RM is almost constant, and the OMS is approximately 5 and $10 \%$ of the smoothed maximum and minimum in the area of at least 0.5 and $15 \mu \mathrm{m}$.

\section{References}

[1] V.I. Korneev, A.G. Sousse, A.I. Guild. Red mud, properties, warehousing, application. Moscow: Metallurgy. 1991. 242p. (russian)

[2] N.Ah. Sabirzyanov, S.P. Yatsenko. Hydrochemical methods of complex processing of bauxite. Ekaterinburg: Uro RAS. 2006. 385p. (russian)

[3] A.I. Ivanov, G.N. Kozhevnikov, F.G. Sitdikov, L.P. Ivanova. Complex processing of bauxite. Yekaterinburg: Uro RAS. 2003. 180p. (russian)

[4] L.I. Leontev. Complex processing raw materials. Resources. Technologics. Economy. 2005. No.7. P.1014. (russian)

[5] L.I. Leontiev, N.A. Vatolin, S.V. Shavrin, N.S. Shumakov. Pyrometallurgical processing of complex ores. Moscow: Metallurgy. 1997. 432p. (russian)

[6] I.N. Tanutrov, M.N. Sviridova, V.V. Kashin, A.N. Savenya. A New Technology for Coprocessing Man Made Wastes. Metallurgy of Nonferrous Metals. 2013. Vol.54. No.2. P.136-142.

[7] I.N. Tanutrov, M.N. Sviridova. The directions of improvement of methods of processing of technogenic wastes of the Ural region. Ecology and industry of Russia. 2015. Vol.19. No.8. P.31-35. (russian)

[8] O.V. Nechvoglod, and A.G. Upolovnikova. The study of the phase composition of the products of electrochemical oxidation of sulfide granules of the system $\mathrm{Cu}_{1.96} \mathrm{~S}-\mathrm{Ni}_{3} \mathrm{~S}_{2}-\mathrm{Cu}-\mathrm{Ni}$. Butlerov Communications. 2019. Vol.57. No.3. P.149-154. DOI: 10.37952/ROI-jbc-01/19-57-3-149 
Full Paper_I.N. Tanutrov, M.N. Sviridova, S.A. Lyamkin, Yu.A. Chesnokov, L.A. Ovchinnikova, and L.A. Marshuk [9] S.N. Golovin, M.N. Yaprintsev, I.G. Ryltsova, and O.E. Lebedeva. Influence of nature of the precipitating agent and chemical-thermal treatment on the phase composition of cerium-containing layered double hydroxides. Butlerov Communications. 2018. Vol.56. No.12. P.126-130. DOI: 10.37952/ROI-jbc-01/1856-12-126

[10] A.N. Popova, Ch.N. Barnakov, G.P. Khohlova. The study of the structural characteristics of carbon materials by mean of XRD analysis. Butlerov Communications. 2018. Vol.56. No.11. P.153-159. DOI: 10.37952/ROI-jbc-01/18-56-11-153

[11] A.N.Gabdullin, E.A. Nikonenko, T.M. Klyuev, and V.F. Markov. Chemical and phase composition of oxidized nickel ores of the Kulikovsky deposit - raw materials for the production of magnesium compounds, Fe-Ni-containing concentrates, $\mathrm{SiO}_{2}$. Butlerov Communications. 2018. Vol.55. No.8. P.156-161. DOI: 10.37952/ROI-jbc-01/18-55-8-156

[12] A.E. Buntin, R.O. Sirotkin, and O.S. Sirotkin. Features of chemical structure, properties and technology of inorganic products based on oxides. Butlerov Communications. 2018. Vol.53. No.2. P.153-160. DOI: 10.37952/ROI-jbc-01/18-53-2-153 